\title{
Penerapan Metode Discovery Learning dengan Pendekatan Adiksimba untuk Meningkatkan Ketrampilan Bertanya dan Hasil Belajar Pendidikan Kewarganegaraan
}

\author{
Elly Kristini ${ }^{1 *}$ \\ ${ }^{1}$ SMP Negeri 5 Melaya, Jembrana, Bali, Indonesia
}

\section{ART I CLE I N F O}

Article history:

Received March 16, 2021

Revised March 25, 2021

Accepted June 10, 2021

Available online August 25, 2021

Kata Kunci:

AdikSimba, Discovery Learning, Penilaian Tindakan Kelas

Keywords:

AdikSimba, Classroom Action

Research, Discovery Learning

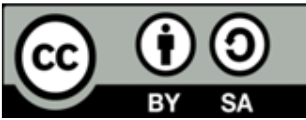

This is an open access article under the CC BY-SA license.

Copyright $(2021$ by Author. Published by Universitas Pendidikan Ganesho.

\begin{abstract}
A B S T R A K
Keberhasilan proses pembelajaran sangat bergantung pada keaktivan siswa dan pemahaman siswa. Pemilihan metode pembelajaran yang tepat dapat menjadi kunci keberhasilan dalam suatu proses pembelajaran. Penelitian ini bertujuan untuk mengetahui efektivitas salah satu metode pembelajaran yaitu penerapan metode Discovery Learning dengan pendekatan teknik AdikSimba untuk meningkatkan ketrampilan bertanya siswa dan output hasil belajar siswa. Penelitian ini merupakan penelitian tindakan kelas. Korelasi antara ketrampilan bertanya siswa dengan nilai belajar siswa dianalisis dengan analisis statistic bivarat. Hasil penelitian menunjukan adanya korelasi positif antara frekuensi bertanya dengan hasil belajar siswa. Terdapat peningkatan rerata skor hasil belajar siswa dari 65.72 (Prasiklus), menjadi 70.76 (Siklus I), dan 81.24 (Siklus II). Terdapat perbedaan yang signifikan antara rerata skor hasil belajar siswa pada siklus II dibandingkan dengan prasiklus atau siklus I. Dapat disimpulkan bahwa penerapan metode pembelajaran Discovery Learning dengan pendekatan AdikSimba mampu meningkatkan ketrampilan bertanya siswa dan menghasilkan output berupa peningkatan skor belajar siswa.
\end{abstract}

\section{A B S T R A C T}

Student liveliness is considered an essential factor involved in their understanding. The right learning method plays a crucial role in the process of sudent learning. This research aimed to evaluate the Discovery Learning method's effectiveness with the AdikSimba technique to improve student liveliness thus improve learning outcomes as well. This research was classroom action research to statistically assay the correlation between students questioning skills and learning outcomes. The data of students questioning score and learning outcome were assayed statistically using Pearson. A positive correlation between the question frequence and student learning outcomes was produced. An increase in the mean score of student learning outcomes from 65.72 (Pre-cycle), to 70.76 (Cycle I), and 81.24 (Cycle II) were also produced, with statistically significant differences. As the conclusion, the application of the Discovery Learning learning method with the AdikSimba question probing approach improves students questioning skills and learning score.

\section{PENDAHULUAN}

Perkembangan sains dan teknologi saat ini berlangsung dengan sangat cepat sehingga menuntut dunia pendidikan untuk mewujudkan institusi pendidikan yang mampu bertahan menghadapi perubahan jaman serta mampu mengembangkan kualitas sumber daya manusia (SDM) yang siap berkompetisi di era Revolusi Industri 4.0 (Harto, 2018). SDM menjadi kunci penting dalam mewujudkan misi Making Indonesia 4.0, dimana masa depan bangsa bergantung pada kualitas para generasi muda dan menuntut mereka untuk memiliki kualitas, daya saing, dan penguasaan teknologi (Hideyuki \& Barry, 2016). Dalam hal ini institusi pendidikan memainkan peran yang sangat mendasar dalam melahirkan SDM yang berkualitas ini (Setyoningrum et al., 2020).

Revolusi Industri di era 4.0 membawa berbagai tantangan dalam dunia pendidikan. Sangat penting bagi para siswa di era ini untuk dibekali dengan kemampuan memanfaatkan teknologi informasi dan komunikasi serta ketrampilan kolaboratif yang mampu mengarahkan mereka pada pembelajaran 
seumur hidup (lifelong learner). Selain itu, para siswa juga harus dibekali dengan kemampuan berfikir kritis dan kreatif serta kemampuan berkomunikasi. Pendidikan di era 4.0 harus mampu berperan sebagai platform yang mendukung kesuksesan Revolusi Industri 4.0 (Bonfield et al., 2020). Pendidikan yang baik harus mampu melatih berbagai softskill para siswa terutama untuk mengatasi berbagai masalah yang akan dihadapi dalam kehidupan (Özreçberoğlu \& Çağanağa, 2018). Hal ini dapat diwujudkan dengan melaksanakan pembelajaran abad 21 yang mencantumkan hal-hal mendasar yang harus dimiliki para siswa sebagai bekal untuk menghadapi tuntutan jaman, terutama yaitu cognitive skills, intrapersonal skills, interpersonal skills, dan technical skills, termasuk di dalamnya adalah problem solving, critical thinking, dan system thinking (Geisinger, 2016).

Penerapan kurikulum 2013 yang tengah dilaksanakan bukan berjalan tanpa menyertakan berbagai permasalahan. Berbagai institusi pendidikan tengah menghadapi berbagai jenis permasalahan selama penerapan kurikulum pendidikan ini. SMP Negeri 5 Melaya, Jembrana, Bali merupakan salah satu institusi pendidikan yang tengah menghadapi berbagai permasalahan selama penerapan Kurikulum 2013, diantaranya adalah rendahnya partisipasi siswa selama proses pembelajaran. Selain itu, para siswa juga kurang mampu berinovasi, berfikir kritis, serta berfikir stategis dan demokratis. Permasalahanpermasalahan tersebut selanjutnya berimbas pada rendahnya pemahaman dan nilai hasil belajar. Kualitas proses belajar mengajar sangat mempengaruhi output dari proses tersebut. Penentuan model pembelajaran yang akan digunakan oleh para guru sangat menentukan keberhasilan suatu proses pembelajaran, sehingga sangat penting untuk menentukan metode pembelajaran yang sesuai agar siswa dapat meningkatkan kualitas belajarnya dan menghasilkan output berupa peningkatan hasil belajar siswa. Proses pembelajaran di SMP Negeri 5 Melaya saat ini masih didominasi oleh guru (teacher centered) sehingga keaktifan siswa sulit untuk ditingkatkan. Siswa terkesan pasif dan proses pembelajaran tersebut juga cenderung mematikan daya inovatif dan kreatifitas siswa. Permasalahan ini menjadi salah satu probelematika yang dihadapi di berbagai institusi Pendidikan. Kondisi ini menunjukan bahwa proses belajar mengajar masih belum berjalan secara maksimal dan masih didominasi dengan kegiatan ceramah (Desyandri et al., 2019).

Perubahan paradigma pendidikan dari teacher-centered learning menjadi student-centered learning disertai dengan perubahan berbagai metode-metode pembelajaran yang harus dikembangkan. Metode-metode pembelajaran tersebut harus mampu meningkatkan keaktifan mahasiswa untuk menggali informasi-informasi yang dibutuhkan untuk menunjang proses pembelajaran (Wijayati et al., 2019). Kualitas proses pembelajaran dapat ditingkatkan dengan penerapan pembelajaran yang mengedepankan kemampuan bertanya siswa, salah satunya melalui strategi pembelajaran AdikSimba. AdikSimba merupakan pendekatan pembelajaran dimana peserta didik diperkenalkan pada berbagai pengalaman dengan tujuan untuk mengidentifikasi suatu informasi melalui berbagai kata tanya yaitu $5 \mathrm{~W} 1 \mathrm{H}$ (What, Who, Where, When, Why, How) atau apa, siapa, kapan, dimana, mengapa, dan bagaimana (Priyanto et al., 2018). Pertanyaan (Question) merupakan salah satu strategi yang mampu meningkatkan kemampuan pemahaman siswa, terutama melalui peningkatan kemampuan dan keaktifan membaca. Strategi pembelajaran ini merupakan strategi elaborasi yang terbukti efektif dalam proses penerimaan informasiinfromasi baru oleh para siswa. Kemudahan proses penyaluran informasi tersebut membuat informasi tersebut menjadi lebih bermakna (Tetu et al., 2019).

Pada beberapa penelitian, peningkatan kemampuan bertanya siswa terbukti berkorelasi secara positif terhadap hasil belajar siswa (Nurazizah et al., 2019; Priyanto et al., 2018; Sastra et al., 2020). Strategi pembelajaran AdikSimba ini merupakan model pembelajaran Discovery Learning, dimana siswa dibimbing untuk memahami konsep, arti, dan hubungan melalui proses intuitif untuk mencapai suatu kesimpulan (Rahman, 2017). Dengan mengacu pada hal-hal tersebut, peneliti hendak mengetahui efektivitas penerapan metode Discovery Learning di SMP Negeri 5 Melaya dalam mengatasi permasalahanpermasalahan proses pembelajaran SMP Negeri 5 Melaya yang dievaluasi melalui peningkatan ketrampilan dan hasil belajar siswa. Penelitian ini bertujuan untuk mengetahui efektivitas penerapan metode Discovery Learning dengan pendekatan teknik AdikSimba untuk meningkatkan ketrampilan bertanya siswa dan output hasil belajar siswa.

\section{METODE}

Desain penelitian ini adalah Penelitian Tindakan Kelas yang terdiri dari dua siklus (siklus I dan II) dengan masing-masing dengan empat tahap penelitian yaitu perencanaan, pelaksanaan, pengamatan (observasi) dan refleksi. Tahapan penelitian dimulai dari tahap prasiklus yang dilakukan untuk menentukan subjek penelitian pada siklus I dan II. Indikator pencapaian pada penelitian ini adalah adanya peningkatan rerata hasil belajar siswa (subjek penelitian), dibandingkan dengan hasil pada prasiklus atau siklus sebelumnya. Kegiatan yang dilaksanakan pada tahap perencanaan mencakup penyiapan materi dan 
bahan ajar, metode dan strategi mengajar, serta teknik dan instrumen observasi. Materi yang diberikan adalah PPKn dengan sub-pokok bahasan yaitu Proses Perumusan Pancasila sebagai Dasar Negara. Tahap pelaksanaan berupa implementasi dari semua rencana pada tahap perencanaan. Subjek penelitian dibimbing untuk menyusun dan mengajukan pertanyaan melalui berbagai kata tanya yaitu apa, siapa, kapan, dimana, mengapa, dan bagaimana. Selanjutnya pada tahap pengamatan (observasi) dilakukan proses pengamatan terhadap dampak atau hasil dari tindakan yang dilaksanakan atau diterapkan terhadap subjek penelitian. Observasi diukur melalui dua data yaitu (1) skor bertanya yang diperoleh dari jumlah pertanyaan yang diajukan oleh masing-masing siswa dimana setiap satu pertanyaan akan mendapatkan skor 1 dan (2) skor hasil belajar yang berupa nilai hasil belajar yang diperoleh melalui instrumen observasi berupa sepuluh soal pilihan ganda dan dua buah soal uraian yang diturunkan dari indikator pembelajaran.

Dan pada tahap akhir yakni refleksi dilakukan analisis data yang diperoleh dari tahap observasi, yang kemudian dilanjutkan dengan pengkajian hasil atau dampak dari tindakan yang dilaksanakan pada siklus sebelumnya. Hasil refleksi pada siklus I digunakan sebagai dasar dalam pelaksanaan siklus II. Indikator keberhasilan pada setiap siklus adalah adanya penurunan jumlah sujek penelitian yang memperoleh nilai dibawah KBM (70) dan adanya peningkatan frekuensi bertanya dan rerata nilai dibandingkan dengan siklus sebelumnya. Secara lebih rinci rancangan pelaksanaan penelitian dapat dilihat pada gambar 1.

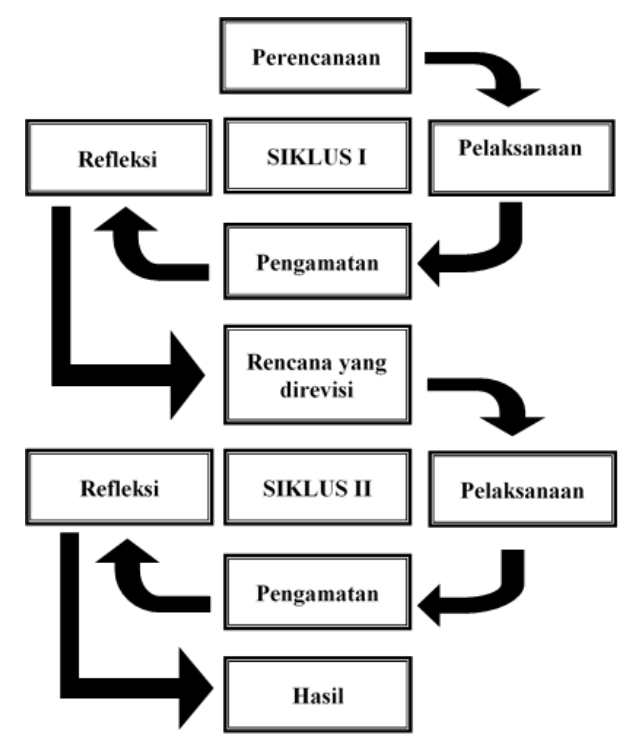

Gambar 1. Desain penelitian tindakan kelas

Penelitian dilaksanakan di SMP Negeri 5 Melaya. Subjek ditentukan pada tahap prasiklus. Subjek pada penelitian ini adalah siswa kelas VII B SMP Negeri 5 Melaya yang tidak memenuhi skor Ketuntasan Belajar Minimal (KBM) yaitu 70 pada prasiklus. Mata pelajaran yang diberikan adalah PPKn dengan subpokok bahasan yaitu Proses Perumusan Pancasila sebagai Dasar Negara. Sejumlah 32 siswa 17 siswa laki-laki dan 15 siswa perempuan) mengikuti proses belajar pada prasiklus dengan metode pembelajaran konvensional berupa ceramah (teacher centered). Siswa yang tidak memenuhi skor KBM pada prasiklus selanjutnya menjadi subjek penelitian pada siklus I dan II dimana pada siklus tersebut subjek penelitian akan mengikuti proses belajar dengan menerapkan metode Discovery Learning dengan pendekatan AdikSimba. Data yang diperoleh dari penelitian ini yakni berupa skor bertanya dan skor hasil belajar yang diperoleh melalui instrument observasi. Data dianalisis secara statistik dengan metode analisis deskriptif berupa mean, standar deviasi, skor maksimum, skor minimum, rentangan, interval dan frekuensi. Korelasi antara skor bertanya dan skor hasil belajar dianalisis dengan metode analisis korelasi bivariate Pearson. Perbedaan rerata skor hasil belajar pada siklus I dan II dibandingkan dengan prasiklus dianalisis dengan uji t tidak berpasangan, sedangkan perbedaan rerata skor belajar antara siklus I dan II dianalisis dengan uji t berpasangan. Analisis statistik menggunakan program IBM SPSS Statistics versi 25. Hipotesis pada penelitian ini adalah bahwa penerapan metode Discovery Learning dengan pendekatan AdikSimba mampu meningkatkan keterampilan bertanya siswa sehingga menghasilkan output berupa peningkatan hasil belajar siswa. 


\section{HASIL DAN PEMBAHASAN}

Tahap prasiklus diikuti oleh sebanyak 32 siswa kelas VII B SMP Negeri 5 Melaya. Setelah mengikuti proses pembelajaran dan memperoleh skor hasil belajar, sebanyak 17 siswa mendapatkan skor hasil belajar dibawah KBM (70). 17 siswa tersebut selanjutnya menjadi subjek penelitian pada penelitian siklus I dan II.

Tabel 1. Analisis deskriptif skor hasil belajar pada prasiklus, siklus I, dan siklus II

\begin{tabular}{lccc}
\hline \multicolumn{1}{c}{ Deskripsi } & Prasiklus & Siklus I & Siklus II \\
\hline Mean & 65.72 & 70.76 & 81.24 \\
Standar Deviasi & 9.72 & 9.32 & 11.58 \\
Skor maksimum & 80 & 87 & 66 \\
Skor minimum & 50 & 57 & 98 \\
Rentangan & 30 & 30 & 32 \\
\hline
\end{tabular}

\section{Prasiklus}

Pembelajaran pada prasiklus tidak mengaplikasikan metode pembelajaran Discovery Learning berbasis AdikSimba. Nilai deskriptif statistik pada prasiklus ditampilkan pada Tabel 1 dan distribusi frekuensi hasil belajar ditampilkan pada Tabel 2. Pada prasiklus, sebanyak 34.37\% memperoleh skor sekitar rata-rata, 37.5\% memperoleh skor di bawah rata-rata, dan $28.13 \%$ memperoleh skor di atas ratarata (Tabel 2). Dengan mengacu pada aturan criterion referenced, dinyatakan bahwa sebanyak 20 (62.50\%) skor merupakan kategori sedang (B3) dan sebanyak 5 (15.63\%) skor merupakan kategori tinggi (B1). Rerata skor pada prasiklus termasuk dalam kategori sedang (B3).

Tabel 2. Distribusi frekuensi skor hasil belajar pada prasiklus

\begin{tabular}{cccc}
\hline Interval & Nilai tengah & Frekuensi absolut & Frekuensi relatif \\
\hline $49.95-54.97$ & 52.46 & 7 & 21.875 \\
$54.98-60.01$ & 57.50 & 2 & 6.25 \\
$60.02-65.04$ & 62.53 & 3 & 9.375 \\
$65.05-70.08$ & 67.56 & 11 & 34.375 \\
$70.09-75.11$ & 72.60 & 4 & 12.5 \\
$75.12-80.15$ & 77.64 & 5 & 15.625 \\
\hline \multicolumn{2}{r}{ TOTAL } & $\mathbf{3 2}$ & $\mathbf{1 0 0}$ \\
\hline
\end{tabular}

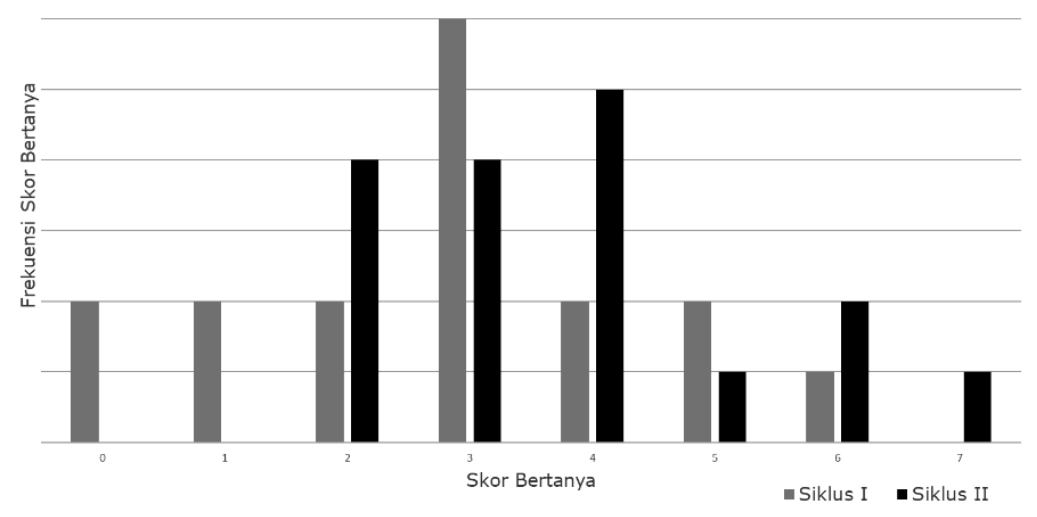

Gambar 2. Frekuensi skor bertanya pada siklus I dan II

\section{Siklus I}

Tahap perencanaan pada siklus I menggunakan dasar analisis hasil dari prasiklus. Dilakukan pengkajian ulang terhadap Rencana Pelaksanaan Pembelajaran (RPP) yang berkonklusi bahwa pembelajaran pada prasiklus tidak didukung dengan kemampuan bertanya yang benar sehingga kurang efektif dalam mengomunikasikan materi ajar yang menuntut pemahaman konsep secara mendalam. Hal ini kemudian menimbulkan mikonsepsi pada subjek penelitian (siswa) yang berimbas pada tingginya jumlah siswa yang memperoleh skor hasil belajar di bawah KBM. 
Tabel 3. Distribusi frekuensi skor hasil belajar pada siklus I

\begin{tabular}{cccc}
\hline Interval & Nilai tengah & Frekuensi absolut & Frekuensi relatif \\
\hline $56.95-62.88$ & 59.92 & 3 & 17.65 \\
$62.89-68.82$ & 65.86 & 5 & 29.41 \\
$68.83-74.76$ & 71.80 & 3 & 17.65 \\
$74.77-80.70$ & 77.74 & 4 & 23.53 \\
$80.71-86.64$ & 83.68 & 1 & 5.88 \\
$86.65-92.58$ & 89.62 & 1 & 5.88 \\
\hline & & $\mathbf{1 7}$ & $\mathbf{1 0 0}$ \\
\hline
\end{tabular}

Pada siklus I diimplikasikan metode Discovery Learning berbasis AdikSimba untuk meningkatkan kemampuan bertanya siswa. Proses pembelajaran berfokus pada aktivitas siswa dalam mengerjakan tugas diskusi. Masing-masing anggota kelompok wajib mengajukan pertanyaan dengan pendekatan AdikSimba. Pada tahap observasi, tampak bahwa siswa dengan kemampuan akademis yang lebih tinggi menjadi tutor bagi siswa lain dengan kemampuan akademis yang lebih rendah. Pertanyaan-pertanyaan yang diajukan siswa didominasi oleh pertanyaan-pertanyaan yang hanya sebatas mengasah ketrampilan mengingat dan kurang dalam kemampuan memahami materi secara konkret dan lebih mendalam. Selain itu, siswa masih cenderung kurang percaya diri dan ragu dalam merespon sanggahan, yang menunjukan masih adanya miskonsepsi pada siswa. Nilai deskriptif statistik pada siklus I ditampilkan pada Tabel 1 dan distribusi frekuensi hasil belajar ditampilkan pada Tabel 3. Perolehan skor hasil belajar pada siklus I menunjukan bahwa sebanyak $\mathbf{1 7 . 6 5 \%}$ siswa memperoleh skor hasil belajar sekitar rata-rata, sedangkan sebanyak 37.29\% di atas rata-rata (Tabel 3). Tampak adanya peningkatan rerata skor hasil belajar pada siklus I (70.76) dibandingkan dengan prasiklus (65.72). Berdasarkan acuan criterion referenced, dinyatakan bahwa sebanyak 8 (47.06\%) skor merupakan kategori sedang (B3) dan sebanyak 6 (35.29 \%) skor merupakan kategori tinggi (B1). Rerata skor pada siklus I termasuk dalam kategori sedang (B3).

Analisis korelasi bivariate Pearson pada siklus I menghasilkan korelasi positif yang signifikan antara skor bertanya dan skor hasil belajar. Korelasi positif tersebut menunjukan bahwa peningkatan skor bertanya diikuti dengan peningkatan skor hasil belajar. Korelasi yang ditimbulkan antara kedua variabel tersebut bersifat searah atau berbanding lurus. Penerapan metode pembelajaran tersebut terbukti mampu mengurangi miskonsepsi siswa. Selain itu metode tersebut juga meningkatkan keaktifan siswa, kepercayaan diri dan kepercayaan terhadap kelompok, serta hubungan sosial. Siswa juga mampu mengembangkan skeptisme yang sehat kearah kebenaran yang pasti dan meningkatkan pemahaman konsep secara holistik. Meskipun skor bertanya menunjukan korelasi terhadap skor hasil belajar, namun pada siklus I diketahui sebanyak 47.05\% siswa memperoleh skor hasil belajar dibawah KBM (70). Apabila dibandingkan dengan persentase pada prasiklus (53.13\%), belum terjadi penurunan yang signifikan pada persentase siswa yang memperoleh skor hasil belajar diatas $\operatorname{KBM}(\mathrm{p}>0,05)$.

\section{Siklus II}

Perencanaan pada siklus II didasarkan pada hasil refleksi siklus I dengan melakukan pengkajian ulang terhadap RPP dan metode pelaksanaan tindakan. Hasil refleksi pada siklus I berkonklusi bahwa metode pelaksanaan belum secara optimal meningkatkan keaktifan siswa. Para siswa dengan kemampuan akademis yang lebih rendah masih terlalu bergantung dan mengandalkan pada siswa yang dianggap memiliki kemampuan akademis yang lebih tinggi, namun belum mampu secara maksimal menjadi tutor bagi teman sebayanya. Selain itu, dalam mempresentasikan hasil diskusi kelompoknya, para siswa masih ragu sehingga siswa lainnya mengalami kesulitan dan menimbulkan miskonsepsi. Pertanyaan-pertanyaan yang diajukan masih belum mendalam dan belum mengarah pada pemahaman konsep secara holistik dan hanya terbatas pada pertanyaan-pertanyaan hafalan saja.

Tabel 4. Distribusi frekuensi skor hasil belajar pada siklus II

\begin{tabular}{rccc}
\hline Interval & Nilai tengah & Frekuensi absolut & Frekuensi relatif \\
\hline $56.95-62.88$ & 59.92 & 3 & 17.65 \\
$62.89-68.82$ & 65.86 & 5 & 29.41 \\
$68.83-74.76$ & 71.80 & 3 & 17.65 \\
$74.77-80.70$ & 77.74 & 4 & 23.53 \\
$80.71-86.64$ & 83.68 & 1 & 5.88 \\
$86.65-92.58$ & 89.62 & 1 & 5.88 \\
\hline & & $\mathbf{1 7}$ & $\mathbf{1 0 0}$ \\
\hline
\end{tabular}


Pada siklus II, pembelajaran kooperatif Discovery Learning dengan ketrampilan bertanya berbasis AdikSimba tetap digunakan. Pada Siklus II, aktivitas siswa saat mengerjakan tugas dalam kelompok dibimbing secara lebih efektif dengan menekankan penggunaan literatur atau referensi yang sudah dirujuk sebelumnya. Pengawasan dan perhatian terhadap siswa dilakukan secara lebih intens. Diskusi kelompok dilakukan dengan lebih menyenangkan dengan menggunakan referensi-referensi acuan. Nilai deskriptif statistik pada siklus II ditampilkan pada Tabel 1 dan distribusi frekuensi hasil belajar ditampilkan pada Tabel 4. Skor hasil belajar Siklus II menunjukan sebanyak 17.65\% siswa memperoleh skor hasil belajar sekitar rata-rata, sedangkan sebanyak $47.06 \%$ di atas rata-rata. Rerata skor hasil belajar pada siklus II (81.24) menunjukan peningkatan apabila dibandingkan dengan Siklus I (70.76). Berdasarkan acuan criterion referenced, dinyatakan bahwa sebanyak 3 (17.65\%) skor termasuk kategori sedang (B3) dan sebanyak 8 (47.06 \%) skor termasuk kategori tinggi (B1). Rerata skor pada prasiklus termasuk dalam kategori tinggi (B1). Skor bertanya dan skor hasil belajar pada siklus II menunjukan korelasi positif yang signifikan, sehingga dapat dinyatakan bahwa peningkatan skor bertanya akan diikuti dengan peningkatan skor hasil belajar. Terdapat peningkatan nilai $r$ (nilai korelasi Pearson) dari siklus I yaitu 0.786 menjadi 0.851 pada siklus II, yang menunjukan semakin kuatnya korelasi yang terbentuk antara kedua variabel. Pada siklus II diketahui sebanyak 5 (29.41\%) siswa memperoleh skor hasil belajar dibawah KBM (70). Nilai ini menunjukan penurunan apabila dibandingkan dengan persentase pada siklus I yaitu $47.05 \%$ atau sebanyak 8 siswa. Terdapat perbedaan yang signifikan antara rerata skor hasil belajar siswa pada siklus II dibandingkan dengan prasiklus atau siklus I $(\mathrm{p}<0.05)$.

\section{Pembahasan}

Penelitian ini dilakukan untuk menilai korelasi antara ketrampilan bertanya dengan hasil belajar siswa. Hasil penelitian menunjukan bahwa metode pembelajaran kooperatif Discovery Learning dengan ketrampilan bertanya berbasis AdikSimba (5W1H) mampu meningkatkan ketuntasan belajar PPKN pada siswa kelas VII B SMP Negeri 5 Melaya yang tampak dari adanya perbedaan yang signifikan antara rerata skor hasil belajar siswa pada prasiklus dimana pada tahap ini belum dilakukan proses pembelajaran Discovery Learning berbasis Adik Simba dibandingkan dengan siklus I dan II yang sudah menerapkan proses pembelajaran Discovery Learning berbasis Adik Simba. Hasil yang diperoleh tidak terlepas dari peranan penggunaan metode Discovery Learning, dimana metode ini memiliki tujuan untuk meningkatkan pemahaman konsep , arti, dan hubungan melalui proses intuitif untuk mencapai suatu kesimpulan. Proses penyingkapan atau penemuan dalam pelaksanaan Discovery Learning ini dapat terwujud apabila para siswa terlibat dalam prosesnya dengan mengobservasi, mengklasifikasi, mengukur, memprediksi, menentuan dan menginferensi untuk menemukan berbagai konsep dan prinsip. Proses mental ini dapat dilakukan dengan berbagai langkah yaitu stimulasi, identifikasi masalah, pengumpulan dan pengolahan data, pembuktian, lalu diakhiri dengan generalisasi atau penarikan kesimpulan (Rahman, 2017).

Discovery Learning merupakan sebuah proses mobilisasi dimana seseorang akan mampu menemukan sebuah ide atau informasi baru atau mengembangkan sebuah ketrampilan baru. Metode ini tepat diaplikasikan pada anak-anak, sesuai dengan pandangan Jean Piaget bahwa anak-anak merupakan pemikir yang aktif, yang secara konstan akan mencoba mengonstruksikan sebuah pemahaman (Chase \& Abrahamson, 2018). Dalam pembelajaran Discovery Learning siswa difasilitasi untuk melakukan observasi, eksperimen, atau tindakan-tindakan ilmiah hingga mereka dapat menarik sebuah kesimpulan melalui kegiatan-kegiatan tersebut. Karakteristik dari strategi pembelajaran ini adalah kegiatan eksplorasi dan memecahkan masalah yang secara aktif dilakukan oleh siswa untuk menciptakan, menggabungkan atau mengeneralisasi sebuah pengetahuan serta menggabungkan pengetahuanpengetahuan baru dengan pengetahuan-pengetahuan yang telah ada, sehingga penggunaan model ini mampu mengatasi berbagai masalah yang timbul dari proses pembelajaran teacher-centered learning seperti pembelajaran kurang menarik dan kurang menyenangkannya (Desyandri et al., 2019; Kristin, 2016).

Penerapan Discovery Learning terbukti mampu memberikan pengalaman nyata bagi para peserta didik, meningkatkan kekritisan dan kreatifitas berfikir, membentuk perubahan perilaku ke arah yang positif serta menambah motivasi belajar dan pengetahuan para peserta didik. Selain itu, ditunjukan pula adanya peningkatan hasil belajar para peserta didik (Kristin, 2016; Simamora et al., 2018; Sulfemi \& Yuliana, 2019). Metode ini juga meningkatkan keaktifan siswa untuk mencari dan menemukan solusi terhadap permasalahan-permasalahan yang muncul, serta membantu memperkuat dan menambah kepercayaan diri para peserta didik dalam proses penemuannya (Junaedi, 2020; Rismayani, 2013; Simamora et al., 2018).

Dalam penelitian ini, proses dan tujuan dalam Discovery Learning dapat diwujudkan oleh para peserta didik dengan bantuan penerapan AdikSimba. Strategi pembelajaran ini mampu meningkatkan 
ketrampilan dan keaktifan siswa selama proses belajar mengajar. Melalui metode ini, siswa dibantu dan dibiasakan untuk terampil dan aktif dalam bertanya, berdiskusi, mengkritisi sebuah pendapat dan permasalahan, merespon pendapat dan pertanyaan serta menyelesaikan masalah yang dihadapi selama proses pemahaman informasi. Siswa menjadi mampu menerima informasi dengan lebih tepat dan mudah serta mampu menyimpulkan informasi tersebut secara benar. Dengan memahami informasi secara mandiri, siswa juga terbukti mampu menghasilkan output pembelajaran yang lebih baik yang dibuktikan dengan meningkatkan skor hasil belajar siswa. (Wang et al., 2017) dalam penelitiannya mengemukakan bahwa penerapan peta konsep melalui kata tanya 5W1H terbukti meningkatkan pengetahuan dan berbagai ketrampilan siswa diantaranya kreativitas, berpikir kritis, komunikasi, kolaborasi, dan mengatasi permasalahan. Penelitian lainnya juga melaporkan efektivitas model pembelajaran ini dalam meningkatkan keaktifan dan ketuntasan belajar siswa serta hasil positif lainnya (Priyanto et al., 2018; Ratnayanti et al., 2016; Wirta, 2020).

Metode pembelajaran AdikSimba memperkenalkan berbagai pengalaman untuk mengidentifikasi suatu informasi melalui berbagai kata tanya yaitu 5W1H (What, Where, Who, Why, When dan How) atau apa, dimana, siapa, mengapa, kapan dan bagaimana (Priyanto et al., 2018). Enam pokok pertanyaan tersebut merupakan pertanyaan yang dapat membantu memecahkan permasalahan dan memicu ide-ide (Sahin, 2015). Kegiatan bertanya dalam proses pembelajaran tidak hanya dapat dilakukan dalam kegiatan diskusi atau bekerja kelompok, namun juga dapat diimplikasikan saat para peserta didik menemui kesulitan atau saat mengamati sesuatu. Kegiatan bertanya ini juga dapat dilakukan tidak hanya antar sesama peserta didik, namun juga dengan guru atau narasumber (Yang, 2020). Strategi pembelajaran dengan menggunakan kata-kata tanya ini dilakukan dengan menyajikan rangkaian pertanyaan yang mencirikan dan menggali ide-ide siswa sehingga mereka dapat melakukan proses jump-start thinking yang menghubungkan pengetahuan dan pengalaman siswa dengan pengetahuan baru yang sedang dipelajari. Proses tanya jawab dilakukan dengan cara mengarahkan siswa agar dapat aktif dan berpartisipasi dalam proses pembelajaran. Berbagai penelitian telah membuktikan bahwa strategi pembelajaran ini dapat meningkatkan kemampuan kognitif siswa, meningkatkan ketuntasan belajar dan kemampuan metakognitif siswa (Hartinah et al., 2019).

Strategi pembelajaran berbasis pertanyaan ini telah menunjukan keberhasilan pada berbagai penelitian. Strategi ini terbukti memudahkan proses penyaluran informasi dari guru ke siswa. Siswa terbukti lebih memahami materi ajar setelah penerapan strategi pembelajaran berbasis pertanyaan. Selain itu, ketrampilan dan keatifan membaca siswa juga turut meningkat, disertai dengan peningkatan pencapaian ketuntasan belajar siswa. Melalui metode ini, siswa juga menjadi mampu menyimpulkan sebuah informasi tertentu dan mampu mengingat kembali informasi-informasi yang sebelumnya telah diterima selama proses belajar mengajar, serta mampu secara tepat menganalisis dan mengevaluasi suatu permasalahan (Dahlia, 2019; Hartinah et al., 2019; Tetu et al., 2019).

\section{SIMPULAN}

Berdasarkan hasil penelitian dapat disimpulkan bahwa penggunaan metode discovery learning dengan pendekatan adiksimba secara signifikan mampu meningkatkan nilai hasil belajar siswa. korelasi positif antara frekuensi bertanya dengan hasil belajar siswa. Terdapat peningkatan rerata skor hasil belajar siswa dari 65.72 (Prasiklus), menjadi 70.76 (Siklus I), dan 81.24 (Siklus II). Terdapat perbedaan yang signifikan antara rerata skor hasil belajar siswa pada siklus II dibandingkan dengan prasiklus atau siklus I. Berdasarkan hasil tersebut maka dapat dapat diajukan beberapa saran yakni para guru disarankan untuk mengaplikasikan proses pembelajaran yang ditekankan pada keaktifan siswa serta siswa harus mampu secara cermat dan kritis menyikapi berbagai materi dan permasalahan yang diberikan dalam proses pembelajaran. Meningkatkan keaktifan siswa terbukti mampu meningkatkan pemahaman dan hasil belajar siswa. Keaktifan tersebut dapat dibangun dengan berbagai metode pembelajaran seperti halnya dengan metode pembelajaran kooperatitif Discovery Learning dengan ketrampilan bertanya berbasis AdikSimba $(5 \mathrm{~W} 1 \mathrm{H})$. Berbagai model pembelajaran lainnya harus selalu dikembangkan sehingga dapat meningkatkan berbagai ketrampilan para peserta didik.

\section{DAFTAR RUJUKAN}

Bonfield, C. A., Salter, M., Longmuir, A., Benson, M., \& Adachi, C. (2020). Transformation or evolution?: Education 4.0, teaching and learning in the digital age. Higher Education Pedagogies, 5(1), 223246. https://doi.org/10.1080/23752696.2020.1816847.

Chase, K., \& Abrahamson, D. (2018). Searching for buried treasure: uncovering discovery in discoverybased learning. Instructional Science, 46(1), 11-33. https://doi.org/10.1007/s11251-017-9433-1. 
Dahlia, D. (2019). Peningkatan Hasil Belajar Siswa Kelas VI SD Negeri 1 Sidorejo Melalui Pendekatan Saintifik Pada Materi Pokok Menulis Peristiwa Menggunakan Aspek 5W+1H. Bitnet: Jurnal Pendidikan Teknologi Informasi, 4(2), 1-7. https://doi.org/10.33084/bitnet.v4i2.1049.

Darling-Hammond, L. (2017). Teacher education around the world: What can we learn from international practice? European Journal of Teacher Education, 40(3), 291-309. https: //doi.org/10.1080/02619768.2017.1315399.

Desyandri, D., Muhammadi, M., Mansurdin, M., \& Fahmi, R. (2019). Development of integrated thematic teaching material used discovery learning model in grade $\mathrm{V}$ elementary school. Jurnal Konseling Dan Pendidikan, 7(1), 16. https://doi.org/10.29210/129400.

Geisinger, K. F. (2016). 21st Century Skills: What Are They and How Do We Assess Them? Applied Measurement in Education, 29(4), 245-249. https://doi.org/10.1080/08957347.2016.1209207.

Hartinah, S., Suherman, S., Syazali, M., Efendi, H., Junaidi, R., Jermsittiparsert, K., \& Umam, R. (2019). Probing-prompting based on ethnomathematics learning model: The effect on mathematical communication skills. Journal for the Education of Gifted Young Scientists, 7(4), 1-16. https: //doi.org/10.17478/jegys.574275.

Harto, K. (2018). Tantangan Dosen PTKI Di Era Industri 4.0. Tatsqif Jurnal Pemikiran Dan Penelitian Pendidikan, 16(1), 1-15. https://doi.org/10.20414/jtq.v16i1.159.

Hideyuki, K., \& Barry, D. M. (2016). STEM and ICT Education in Intelligent Environments. Springer International Publishing. https://doi.org/10.1007/978-3-319-19234-5.

Junaedi, D. (2020). Penerapan Model Pembelajaran Discovery Untuk Meningkatkan Hasil Belajar Siswa Pada Pembelajaran Pendidikan Kewarganegaraan. Jurnal Educatio, 6(1), 55-60. https://doi.org/10.31949/educatio.v6i1.209 P-ISSN

Kristin, F. (2016). Analisis Model Pembelajaran Discovery Learning Dalam Meningkatkan Hasil Belajar Siswa SD. Jurnal Pendidikan Dasar PerKhasa, 2(1). https: //doi.org/10.31932/jpdp.v2i1.25.

Kristini, E. (2020). Pembelajaran Berbasis Literasi Berbantuan Media Tik dengan Metode Pemberian Tugas Untuk Meningkatkan Hasil Belajar PPKn Pada Siswa. Mimbar Ilmu, 25(3), 495-508. https: //doi.org/10.23887/mi.v25i3.28376.

Kulsum, U., \& Munib, A. (2017). Penerapan Model Pembelajaran Probing Question (Ppq) Untuk Meningkatkan Kreativitas Siswa Di Kelas Tingkat Sekolah Dasar. Jurnal JPSD (Jurnal Pendidikan Sekolah Dasar), 4(1), 1. https://doi.org/10.26555/jpsd.v4i1.a9479.

Lapoule, P., \& Lynch, R. (2018). The case study method: exploring the link between teaching and research. Journal of Higher Education Policy and Management, 40(5), 485-500. https://doi.org/10.1080/1360080X.2018.1496515.

Mahanal, S., \& Siti Zubaidah. (2017). Model Pembelajaran Ricosre Yang Memberdayakan Keterampilan Berpikir Kreatif. Jurnal Pendidikan, 2(5), 676-685. https://doi.org/10.17977/jptpp.v2i5.9180.

Nurazizah, A., Hartati, T., \& Nuryani, P. (2019). Penerapan Model Reciprocal Teaching Untuk Meningkatkan Keterampilan Membaca Pemahaman Kelas Iv Sd. Jurnal Pendidikan Guru Sekolah Dasar, 4(3), 22-34. https://doi.org/10.17509/jpgsd.v4i3.22902.

Özreçberoğlu, N., \& Çağanağa, Ç. K. (2018). Making it count: Strategies for improving problem-solving skills in mathematics for students and teachers' classroom management. Eurasia Journal of Mathematics, Science and Technology Education, 14(4), 1253-1261. https: //doi.org/10.29333/ejmste/82536.

Priyanto, A. S., Suhardiyanto, A., \& Wijiastuti, I. (2018). Peningkatan Keaktifan Dan Hasil Belajar Peserta Didik Dalam Pembelajaran PPKn Melalui Pendekatan Adik Simba Berbasis Gerai Informasi. Integralistik, XXIX(2),

20-31. https://doi.org/https://doi.org/10.15294/integralistik.v29i2.16698.

Rahman, M. H. (2017). Using Discovery Learning to Encourage Creative Thinking. International Journal of Social Sciences \& Educational Studies, 4(2). https://doi.org/10.23918/ijsses.v4i2sip98.

Ratnayanti, N. M. D., Jampel, I. N., \& Sudana, D. N. (2016). Penerapan Metode Journalist Question ( 5W 1H ) Berbantuan Media Foto Pribadi Untuk Meningkatkan. Mimbar PGSD Undiksha, 4(1), 1-10. https://doi.org/10.23887/jjpgsd.v4i1.7004.

Rismayani, N. L. (2013). Penerapan Model Pembelajaran Discovery Learning Untuk Meningkatkan Hasil Belajar PKN Siswa. Jurnal Pendidikan Kewarganegaraan Undiksha, 1(2). https: //doi.org/10.23887/jpku.v1i2.405.

Sastra, E., Yogica, R., \& Syamsurizal, R. D. (2020). Pengaruh Model Pembelajaran Aktif Tipe Giving Question And Getting Answer Bermuatan Literasi Sains Terhadap Kompetensi Belajar Peserta Didik Pada Materi Virus Di SMA Adabiah Padang. Bioilmi, 6(1), 28-38. https: //doi.org/10.19109/bioilmi.v6i1.5059.

Setyoningrum, D. U., Astuti, R. S., Si, M., \& Diponegoro, U. (2020). Melalui Upaya Pemanfaatan Bonus 
Demografi (Dalam Rangka Menghadapi Tantangan Penyelenggaraan Pemerintahan Era 4.0). Prosiding Simposium Nasional, $1291-1319$. https://doi.org/10.22219/PSNIP.Vol0.No0.III\%7C1291-1319.

Simamora, R. E., Saragih, S., \& Hasratuddin, H. (2018). Improving Students' Mathematical Problem Solving Ability and Self-Efficacy through Guided Discovery Learning in Local Culture Context. International Electronic Journal of Mathematics Education, 14(1), 61-72. https://doi.org/10.12973/iejme/3966.

Sulfemi, W. B., \& Yuliana, D. (2019). Penerapan Model Pembelajaran Discovery Learning Meningkatkan Motivasi Dan Hasil Belajar Pendidikan Kewarganegaraan. Jurnal Rontal Keilmuan PKn, 5(1), 1730. https://doi.org/10.29100/jr.v5i1.1021.

Tetu, F., Simpen, I. W., \& Sutama, P. (2019). Penerapan Strategi Pq4R Untuk Meningkatkan Keterampilan Membaca Intensif Siswa Kelas V Menggunakan Media Teks Cerita Rakyat Rongga Pada Sekolah Dasar Katolik Pau Ndoa Kota Komba, Manggarai Timur. Linguistika: Buletin Ilmiah Program $\begin{array}{llll}\text { Magister Linguistik Universitas } & \text { Udayana, } & \text { 26(1), }\end{array}$ https: //doi.org/10.24843/ling.2019.v26.i01.p07.

Wang, A. H., Huang, I., Hwang, G., Wang, H., Huang, I., \& Hwang, G. (2017). International Forum of Educational Technology \& Society Effects of a Question Prompt-based Concept Mapping Approach on Students ' Learning Achievements, Attitudes and 5C Competences in Project-based Computer Course Activities. Educational Technology and Society, 19(3), 351-364. https://doi.org/https://www.jstor.org/stable/10.2307/jeductechsoci.19.3.351.

Wijayati, N., Kusuma, E., \& Sumarti, S. (2019). Pembelajaran Berbasis Digital Di Jurusan Kimia Fmipa Unnes. Jurnal Inovasi Pendidikan Kimia, 13(1), 2318-2325. https://doi.org/https://journal.unnes.ac.id/nju/index.php/JIPK/article/view/17906.

Wirta, I. K. (2020). Pembelajaran Inquiry dengan Optimalisasi Pertanyaan 5w+1h Sebagai Upaya Meningkatkan Hasil Belajar Geografi. Jurnal Pedagogi Dan Pembelajaran, 3(1), 104. https://doi.org/10.23887/jp2.v3i1.24400.

Yang, X. (2020). The Art of Questioning in English Classroom in Junior Middle School. Journal of Language Teaching and Research, 11(5), 815. https://doi.org/10.17507/jltr.1105.18. 